\title{
Contribution to Understanding the Distribution of 'Chocolate' Flint on the Polish Lowlands in the Early Neolithic: Kruszyn, Site 13
}

\author{
Jacek Kabaciński ${ }^{\mathrm{a}}$
}

\begin{abstract}
'Chocolate' flint was the main raw material used by the Early Neolithic Linear Band Culture (LBK) groups in the Polish Lowlands. Since the second (note) phase of the development of this culture, the early farmers developed a complex system of distribution of 'chocolate' flint within the great-valleys zone of the Lowlands. Concretions of raw flint were transported by the Vistula river from the outcrops located on the southeastern slopes of the Świętokrzyskie (Holy Cross) Mountains to Kuyavia. They were worked into cores and processed in settlements close to the Vistula valley. Cores and blades/flakes were also exported to distant locations to the west as far as the Lower Oder basin area. One would expect the existence of specialised workshops providing materials for such a mass distribution. Kruszyn site I3, Włocławek distr., is the first LBK 'chocolate' flint workshop discovered close to the Vistula river concentrated on production of blades. This site fits well into the LBK flint distribution system developed on the Lowlands.
\end{abstract}

KEY-WORDS: Early Neolithic, Linear Band Culture (LBK), 'chocolate' flint, distribution, workshop

\section{INTRODUCTION}

In the middle of the 6 th millennium BC, the territory of today Poland witnessed the first appearance of farming communities that crossed the Sudeten and Carpathian Mountain passes to the north. According to radiocarbon dates, it seems to have been a rapid colonization process and shortly after settling the loess uplands of southern Poland, the Linear Band Pottery Culture (LBK) groups spread into the fertile soil areas of the northern Polish Lowlands. The economy of LBK was based on agriculture and husbandry and at that time, flint was still a basic raw material for the production of tools for everyday activities.

\footnotetext{
a Institute of Archaeology and Ethnology Polish Academy of Sciences, ul. Rubież 46, 6I-6I2 Poznań, Poland; e-mail: jacek.kabacinski@interia.pl; ORCID: 0000-0002-2II8-2005
} 
8o $\mid$ Kabaciński

The flint industry of the LBK in the Polish Lowlands relied on the utilization of diversified raw materials, however most of it was imported to the Lowlands from the south and southeast although sometimes also locally procured good quality Cretaceous Erratic Baltic flint was used (Kobusiewicz 1997, 1999; Kabaciński 2010).

Within the flint inventories of LBK five different imported raw materials have been recorded, namely 'chocolate', Jurassic-Cracow, Świeciechów (grey white-spotted) and Volhynian flints as well as obsidian (Fig. I). The first one - 'chocolate' flint - was certainly the most common of the five on the Lowlands. It is found within the Upper

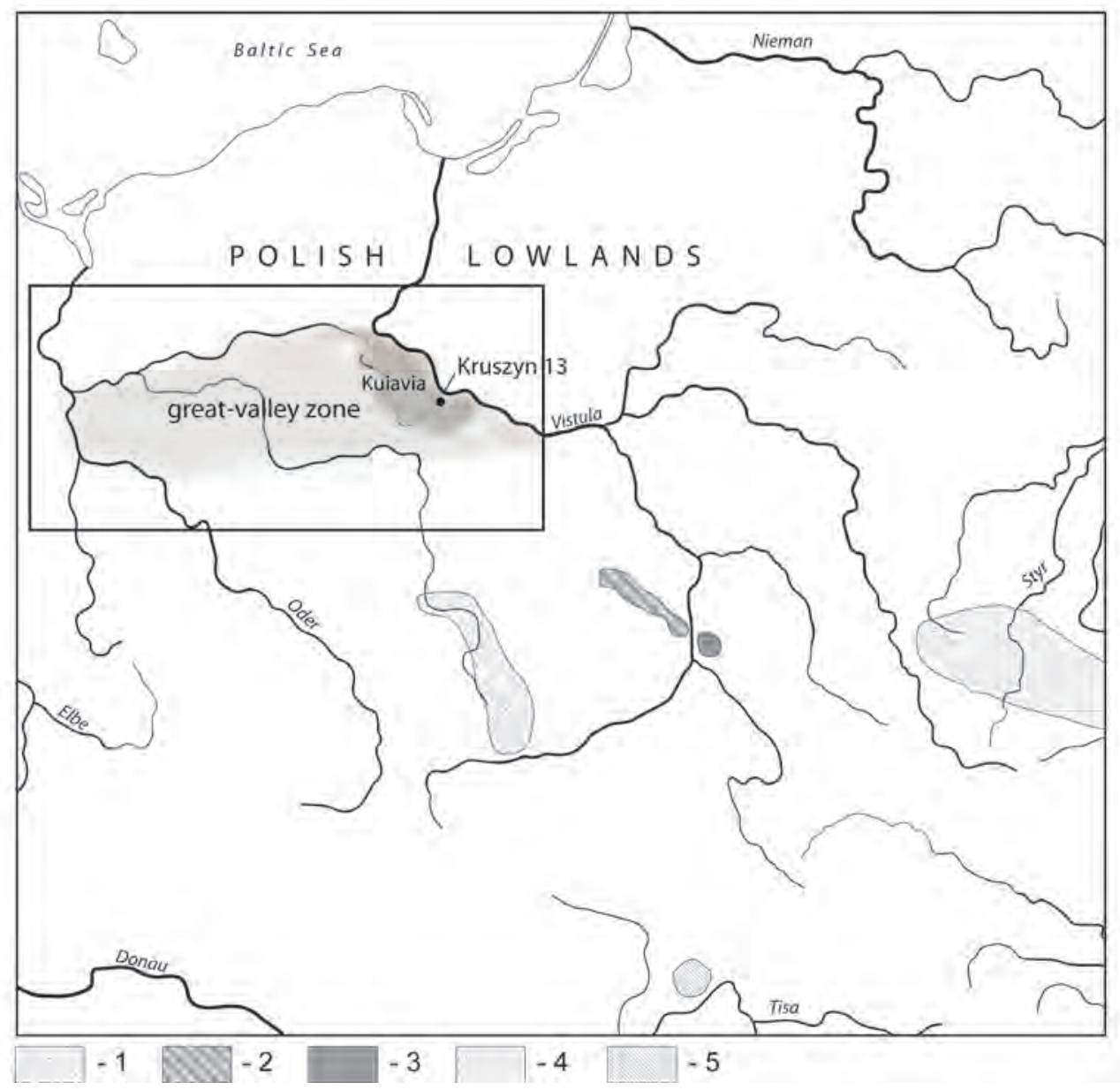

Fig. 1. Main areas and places mentioned in the text and location of outcrops of raw materials used by LBK groups in the Polish Lowlands: 1 - Jurassic flint; 2 - 'chocolate' flint; 3 - Świeciechów flint; 4 - Volhynian flint; 5 - obsidian (acc. to Kabaciński 2010). The black frame indicates the extension of map on Fig. 2. Computer graphics: J. Kabaciński. 
Contribution to Understanding the Distribution of 'Chocolate' Flint $\mid 8 \mathrm{I}$

Jurassic limestone beds located on the southeastern foothills of the Świętokrzyskie (Holy Cross) Mountains (Schild I97I).

\section{DISTRIBUTION OF CHOCOLATE FLINT IN THE GREAT-VALLEYS AREA OF THE POLISH LOWLANDS}

The 'chocolate' flint is recorded already within the earliest LBK settlements known from the Polish Lowlands (Brześć Kujawski Site 3 and Smólsko Site 7, Włocławek district), and intensity of its utilization substantially increased from the beginning of phase II (the 'note' phase, as defined by Czerniak 1994) when it is present on every site, however in different frequency (from 2.9\% in Lipnica Site 29, Bytów district, to $100 \%$ in Łojewo, Inowrocław district). An average share of 'chocolate' flint in raw material structure during II phase is ca. $5 \mathrm{I} \%$ and in phase III even higher - ca. $57 \%$ (Kabaciński 20Io).

The 'chocolate' flint appeared on LBK sites in three different forms: (I) as raw concretions extracted from the limestone beds and still carrying cortex. On such sites a complete technological process took place, covering cortex removal, forming and preparation of cores, cores exploitation and production of tools; (II) the second group of sites are those to which already prepared cores (eventually 'clean' concretions without cortex) had been brought and exploited; (III) sites where that raw material is present exclusively in the form of blades/flakes or tools.

Respecting the form in which 'chocolate' flint appeared on LBK sites, it seems that the Vistula river valley, if not the river itself, is the most obvious route for its mass transportation.

During the initial phase of colonization of the Polish Lowlands (phase I), 'chocolate' flint was found on two sites located at a distance of several kilometres from the Vistula valley and in every case there were ready-to-process cores brought to it, most probably together with the first settlers.

A large-scale colonization of the central part of the Lowlands began along with the beginning of LBK phase II. As collected data suggest, this was synchronized with the appearance of a system of the distribution of 'chocolate' flint that became the dominating flint raw material. In a way, creation of such a system was forced by the extent of the colonized territory. Transportation of tonnes of unworked raw material over a distance of a few hundred kilometers, including the Lower Oder river basin, was not only extremely difficult but unprofitable as well. It required travellers overcoming densely forested areas cut by a net of streams and rivers, different in size and orientation. On the other hand in logistic terms, it was illogical to transport over large distances concretions covered by cortex that was not only a waste material, but also carried the risk of transporting bad quality flint. 
$82 \mid$ Kabacinski

In phase II, three chocolate flint distribution zones are visible (Fig. 2). The first covers a strip of land along the western edge of the Vistula channel, from several to about 40 kilometres wide, where raw material was delivered in the form of unworked concretions. The second zone, within which mainly cores were distributed, was slightly narrower but both zones generally occupy the same area and are functionally related as cores produced from raw concretions were subjected to short-distance distribution. To the west of areas adjacent to the Vistula river valley (zones I and 2) extends a vast territory of continuous but disperse LBK colonization where 'chocolate' flint was distributed in the form of blades/flakes and tools (zone 3 ).

In sum, during the 'note phase', two different 'chocolate' flint distribution areas existed over a large part of the Polish Lowlands stretching from the middle Vistula to the middle Oder river. The first covered most of the Kuyavia (zones I and 2), where raw flint concretions were imported on a mass scale from the outcrops and where short-distance redistribution of ready-to-exploit cores took place. In the second area, to the west of the first one, there was long-distance distribution of blades/flakes and tools from the area of primary import. On sites within this area, the chocolate flint is nothing more than an addendum to the locally procured erratic Cretaceous Baltic Flint. One may suppose its presence there had little economic meaning and is an expression of first of all the extra-utilitarian needs of maintaining contacts with the Kuyavian settlement centre.

During LBK phase III, an important modification of the 'chocolate' flint distribution pattern is observed, as only two distribution zones are recorded on the Lowlands.

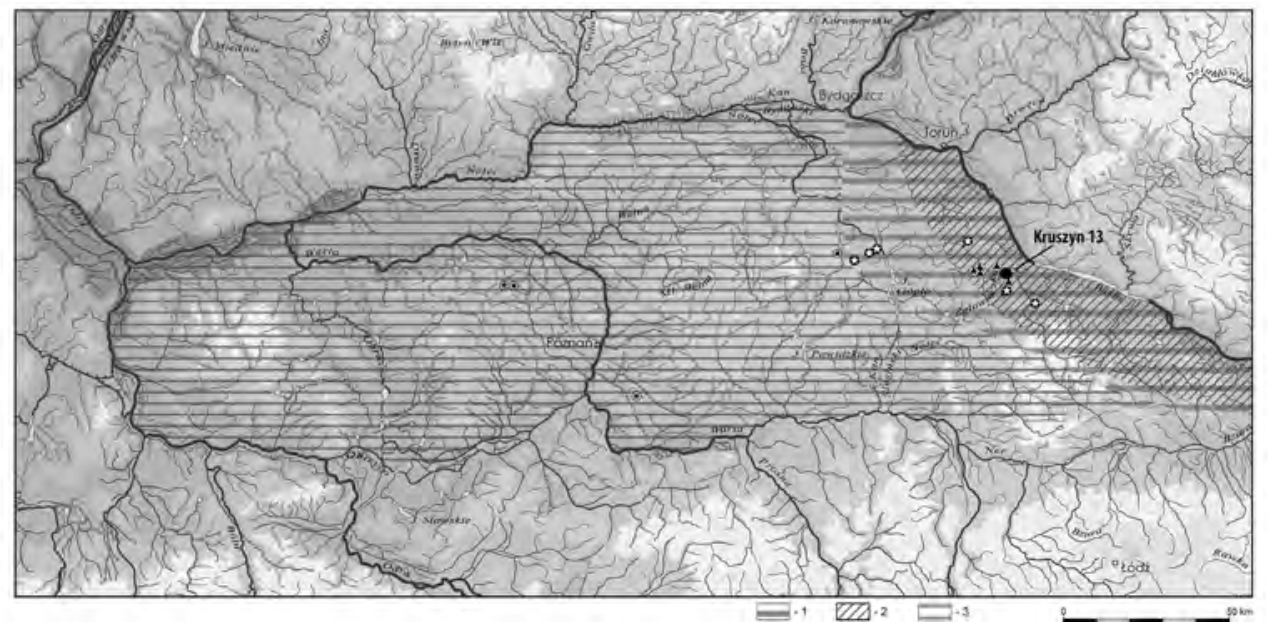

Fig. 2. Linear Band Pottery Culture. Phase II. System of distribution of chocolate flint in the Polish Lowlands (1 - zone I; 2 - zone II; 3 - zone III; star - nodules of raw material; triangle - cores; black dot in circle - blades, flakes and tools). Computer graphics: P. Szejnoga, J. Kabaciński. 
The first extends along the middle Vistula valley and no wider than 20 kilometres (in effect eastern Kuyavia), where raw concretions were imported and on LBK sites a complete cycle of flint working is observed, from core forming to production of tools. Settlements in the second zone, to the west as far as the Oder river valley, were supplied with cores, afterwards exploited there for blades and flakes for tool production. That change is a consequence of the stabilization of the LBK settlement system and the logistic optimisation of the raw material exchanging network. At the same time, the 'chocolate' flint reached its maximum as a dominant raw material with average frequency of about $60 \%$ (Kabaciński 20ro).

There are also other issues related to 'chocolate' flint distribution. The first is the way the chocolate flint reached Kuyavia. In the initial stage of colonization, most probably it was brought by the first settlers. However, in phase II its quantity, especially on Kuyavian sites raised rapidly and certainly an organized system of supply existed since that time. As chocolate flint came to Kuyavia in the form of raw concretions covered by thick cortex, it must have been extracted directly from primary outcrops. Mining of a 'chocolate' flint by LBK groups since phase II is confirmed for flint mine at Tomaszów, Szydłowiec district, as indicated by some of the radiocarbon dates from mining shafts as well as the typology of pre-cores (Schild et al., 1975: 70n.). The evidence of Jurassic flint mining (Lech 198I) suggests it was a typical way of flint acquisition for LBK societies inhabiting Little Poland.

There are various hypotheses on how a chocolate flint was delivered to LBK Kuyavia. Some scholars suggested Mesolithic Janislavician groups played a role as trade middlemen (Kozłowski and Kozłowski 1977). Bogdan Balcer claimed that chocolate flint outcrops were at that time in territory owned by Janislavician people and ${ }_{4} \mathrm{C}$ dates from the Tomaszów mine would confirm that (Balcer 1983: 58). However, the above mentioned techno-typological and chronological arguments support the hypothesis of chocolate flint mining by LBK groups (see also Domańska 1989).

The second hypothesis, advocated by the author of this paper, assumes the independent sourcing of 'chocolate' flint by LBK groups. Jacek Lech has pointed to two possibilities that do not exclude each other. There was either an organized distribution system or independent trips for flint were taken by people from individual settlements (Lech 1979). In the light of such a large quantity of 'chocolate' flint delivered to LBK Kuyavia it seems quite probable it came there by a direct transportation system to supply settlements located near to the Vistula valley with flint rather than through indirect exchange with Mesolithic groups. Water transport, with the help of boats or rafts should be considered, although as yet no trace of evidence for such means of transport is known from an Early Neolithic context.

Much evidence from LBK settlements located close to the Vistula valley shows the processing of 'fresh' 'chocolate' concretions brought straight from quarries already from the beginning of phase II. However, from the point of view of settlement structure, 


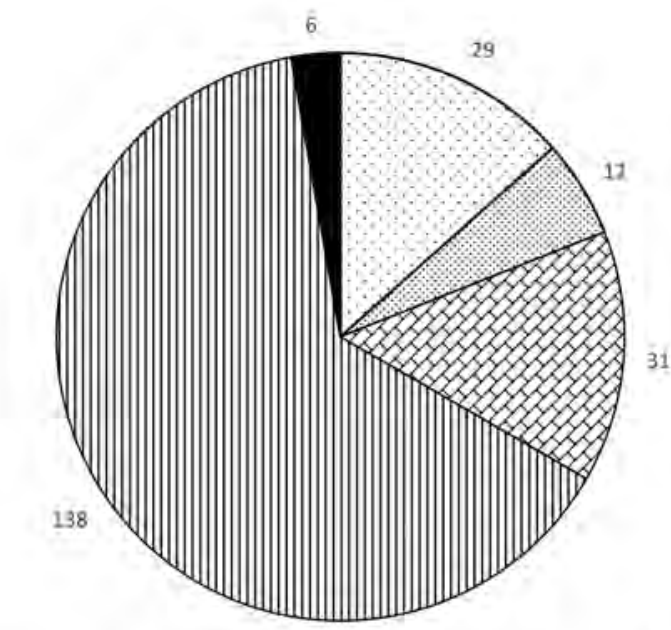

Group
QGroup II

DGroup III
ФGroup IV
Fig. 3. Kruszyn, site 13, Włocławek distr., feature G56. Technological structure of the assemblage.

Group I - preparation of cores and early stage of exploitation of cores; Group II - production of flakes; Group III - production of blades; Group IV - unidentified cores and debitage, chips and chunks; Group V - retouched tools.

Computer graphics: J. Kabaciński.

one would expect sites/workshops oriented toward production of cores and production of blades/flakes in zone I, designated for further distribution to settlements located to the west. Until now, no such core-production workshop had been recorded. However, in Kruszyn Site 13, Włocławek district, the first workshop specialized in blade production has been found.

\section{KRUSZYN, SITE I3, WŁOCŁAWEK DISTRICT}

The site No. I3 (AUT ro4) at Kruszyn was recorded and excavated during the rescue excavations carried out along the Ar highway. In the course of the research a settlement of LBK dated to the 'note' phase (phase II) was excavated. Three typical LBK houses built of rows of wooden posts were found accompanied by several dozens functionally different features (Czekaj-Zastawny 20II). About 40 meters away from the settlement, two distinctly separated features were recorded, marked as G55 and G56. In feature G55, several dozen LBK pottery fragments occurred, while in feature $G_{5} 6$ an assemblage of 216 flint artefacts was found (Kabaciński 20II).

The lithic inventory is very homogenous from the point of view of raw material structure, all but one artefact (a chip) were made of a 'chocolate' flint. The technological structure of the assemblage is also very characteristic. It contains artefacts belonging to five distinct technological groups (for details see Schild 1975; Domańska 1995; Domańska and Kabaciński 2000; see Fig. 3). 
Group I - core preparation and initial core exploitation contains 29 artefacts including I2 cortex flakes, 7 cortex blades, 7 primary crested blades and 4 core trimming flakes. Group II - production of flakes contains i2 flakes removed from single platform cores. To Group III - production of blades - belong 3I blades of which 29 were struck of single platform and the remaining two from opposed platform cores. Group IV of unidentified cores, debitage, chips and chunks contains 138 artefacts including 3 unidentified flakes, I25 chips and to chunks. Group $V$-retouched tools includes 6 tools.

'Chocolate' flint processed in the vicinity of feature G56 was brought to the place in the form of cores still partially covered by cortex. Based on the different kind of cortex identified, some cores were made of concretions extracted directly from original beds while the others represent nodules from secondary beds. The longest artefacts measures $68 \mathrm{~mm}$ what would suggest that cores at the beginning of exploitation were not larger than 8-10 cm in length.

The technological uniformity of the assemblage is striking. With no exceptions all the artefacts are connected with classical core processing and not a single sign of scaled technique was observed. The exploitation of cores was based on well-prepared single platform cores from which first of all blades and later also rare flakes were removed. The edges of the cores were carefully trimmed as indicated by the structure of debitage platforms: $49.1 \%$ facetted, $27.3 \%$ lisse, $7.3 \%$ dihedral and only $3.6 \%$ cortex. No traces of core repair during its processing was recorded. The few tools include three noncharacteristic retouched flakes and blades (Fig. 4).
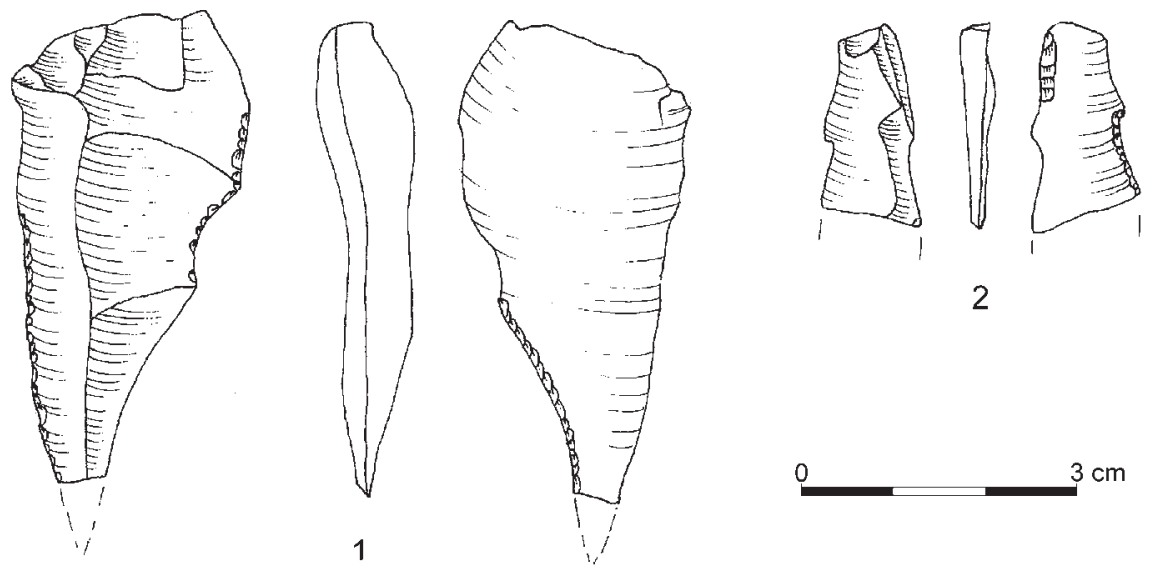

Fig. 4. Kruszyn, site 13, Włocławek distr., feature G56: 1-2 - retouched blades made of 'chocolate' flint. Drawn: J. Sawicka. 


\section{DISCUSSION}

From the functional point of view there is a striking contrast between the analyzed assemblage and other LBK inventories form the Polish Lowlands, as the latter are usually typical household assemblages produced and served to fulfil the everyday needs of the settlements' inhabitants (Kabaciński 20Io). The exceptional nature of this inventory is visible in: (I) the unique raw material structure, with only 'chocolate' flint processed. Such structure is sometimes recorded in LBK contexts, but only in the case when few pieces were found but never in assemblages rich in flints like that from Kruszyn Site I3 (Kabaciński 2OIO); (II) the uniform technological structure related to the exploitation of single platform cores and the lack of the scale technique. Such a situation is never met in LBK assemblages as the scale technique is always present in LBK, usually being the final stage in the technological chain; (III) the lack of retouched tools typical of LBK household assemblages, like endscrapers on flakes and blades, truncations or at least single cases of other types (perforators, drills, scrapers or trapezes), always present in rich collections of flint artefacts. Only a few retouched flakes and blades were encountered in Kruszyn Site I3; (IV) the specific percentage relations in between technological groups, with a well-represented group of objects representing the production of blades group, and with an overwhelming presence of chips and chunks as well as the low share of retouched tools.

These basic dissimilarities of the Kruszyn Site I3 assemblage compared with other site assemblages clearly point to the presence of a flint workshop in the vicinity of feature G56. In it, only 'chocolate' flint was processed and the aim was the production of good quality blades. Only accidentally broken or worse quality blades were left on the spot. It was a special place located outside, and at a substantial distance from, a habitation zone of LBK settlement. Such a location may suggest the workshop production was reserved for export to distant locations within LBK oecumene. The workshop for production of blades from 'chocolate' flint from Kruszyn Site 13 is the first one discovered in the Polish Lowlands and is an important contribution to the discussion on the internal raw material distribution system in the LBK.

\section{REFERENCES:}

Balcer, B. 1983. Wytwórczość narzędzi krzemiennych w neolicie ziem Polski. Wrocław, Ossolineum.

Czekaj-Zastawny, A. 20II. Kultura ceramiki wstęgowej rytej. In I. Sobkowiak-Tabaka (ed.), Osadnictwo pradziejowe, wczesnośredniowieczne i nowożytne na stanowisku Kruszyn I3 (AUT I04), gm. Wtoctawek, woj. kujawsko-pomorskie. Poznań, Institute of Archaeology and Ethnology Polish Academy of Sciences. Manuscript in The National Heritage Board of Poland (Narodowy Instytut Dziedzictwa).

Czerniak, L. 1994. Wczesny i środkowy okres neolitu na Kujawach. Poznań. 
Domańska, L. 1989. Reception of Little Poland flint raw material by Kuiavian Communities of the Band Tradition. In A. Cofta-Broniewska (ed.), Prehistoric contacts of Kuiavian communities with other Europeans Peoples, 77-87. Archeologia Interregionalis io.

Domańska, L. 1995. Geneza krzemieniarstwa kultury pucharów lejkowatych na Kujawach. Łódź.

Domańska, L. and Kabaciński, J. 200o. Krzemieniarstwo społeczności późnoneolitycznych. In A. Kośko (ed.), Archeologiczne badania ratownicze wzdtuż trasy gazociagu tranzytowego, t. III, Kujawy, cz. 4, 379-39i. Poznań.

Kabaciński, J. 20Io. Przemiany wytwórczości krzemieniarskiej spoteczności kultur wstegowych strefy wielkodolinnej Niżu Polskiego. Poznań.

Kabaciński, J. 20II. Wytwórczość krzemienna społeczności kultury ceramiki wstęgowej rytej na stanowisku nr I3 (AUT I04) w Kruszynie. In I. Sobkowiak-Tabaka (ed.), Osadnictwo pradziejowe, wczesnośredniowieczne i nowożytne na stanowisku Kruszyn I3 (AUT I04), gm. Wtoctawek, woj. kujawsko-pomorskie. Poznań, Institute of Archaeology and Ethnology Polish Academy of Sciences. Manuscript in The National Heritage Board of Poland (Narodowy Instytut Dziedzictwa).

Kobusiewicz, M. 1997. Sources of Flint on the West Polish Plain. In R. Schild and Z. Sulgostowska (eds), Man and Flint. Proceedings of the VII-th International Flint-Symposium: Warszawa - Ostrowiec Swiętokrzyski, September 1995, 83-90. Warszawa.

Kobusiewicz, M. 1999. Ludy towiecko-zbierackie pótnocno-zachodniej Polski. Poznań.

Kozłowski, J. K. and Kozłowski, S. K. 1977. Epoka kamienia na ziemiach polskich. Warszawa.

Lech, J. 1979. Krzemieniarstwo w kulturze społeczności ceramiki wstęgowej rytej w Polsce. Próba zarysu. In W. Wojciechowski (ed.) Początki neolityzacji Polski potudniowo-zachodniej, I2I-I36. Wrocław.

Lech, J. 198I. Górnictwo krzemienia spoteczności wczesnorolniczych na Wyżynie Krakowskiej. Koniec VI tysiąclecia - I potowa IV tysiąclecia p.n.e. Wrocław-Warszawa-Kraków-Gdańsk-Łódź.

Schild, R. 197ı. Lokalizacja prahistorycznych punktów eksploatacji krzemienia czekoladowego na północno-wschodnim obrzeżeniu Gór Świętokrzyskich. Folia Quaternaria 39: I-6I.

Schild, R., Marczak, M. and Królik, H. 1975. Późny mezolit. Próba wieloaspektowej analizy otwartych stanowisk piaskowych. Wrocław-Warszawa-Kraków-Gdańsk. 
